\title{
PROBLEMATIKA PEMBELAJARAN BAHASA ARAB
}

\section{Takdir}

Institut Agama Islam Muhammadiyah Sinjai

$$
\begin{aligned}
& \text { تجريد } \\
& \text { وتعليم اللغة العربية في اندونيسيا له مشكلات كثيرة سواء كانت مشكلات اللغوية أم } \\
& \text { مشكلات غير اللغوية. ومشكلات اللغوية كمثل علم الأصوات والصرف والنحو } \\
& \text { والآخر ومشكلات غير اللغوية كمثل دوافع التعليم و وسائل التعليم وطرائق التعليم وبيئة } \\
& \text { اللغوية وغيرها. ولمشكلات التعليم أنواع كثيرة بناء على أحوال الطلبة وبيئة التعليمية. } \\
& \text { وهذا البحث يعبر عن مشكلات تعليم اللغة العربية في أندونسيا وتحليلها } \\
& \text { مفتاح الرشيدية: اللغة العربية - مشكلات اللغوية - مشكلات غير اللغوية - طريقة } \\
& \text { التعليم }
\end{aligned}
$$

\begin{abstract}
Abstrak
Pengajaran bahasa Arab di Indonesia sering kali menghadapi problem linguistik dan nonlinguistic yang harus segera dituntaskan. Problem linguistik, seperti fonetik, morfologi, dan struktur, sedangkan problem non-linguistik, antara lain, motivasi belajar, sarana belajar, metode pengajaran, waktu belajar, dan lingkungan pembelajaran. Persoalan pembelajaran bahasa sangat bervariasi sesuai dengan usia pelajar dan lingkungan tempat belajar. Artikel ini mengungkap problematika pengajaran bahasa Arab di Indonesia sekaligus bagaimana cara mengatasinya.
\end{abstract}

Kata Kunci: Bahasa Arab, Pembelajaran, Problem Linguistik, Problem NonLinguistik, Metode Pengajaran

\section{PENDAHULUAN}

ahasa Arab, meskipun diakui sebagai bahasa kitab suci, tidak berpengaruh B secara signifikan terhadap sikap belajar siswa dan hasil belajarnya. Karena itu, bahasa Arab seharusnya dibelajarkan oleh orang yang menguasai bahasa Arab dan memahami pembelajarannya secara akademik dan pedagogik. Dan, pengetahuan guru tentang problematika pengajaran Bahasa Arab mutlak diperlukan agar ia mampu menemukan solusi yang tepat dalam membelajarkannya.

Problem pembelajaran bahasa Arab yang paling serius untuk ditangani adalah keseriusan belajar siswa dan keseriusan guru dalam mengajar. Keseriusan 


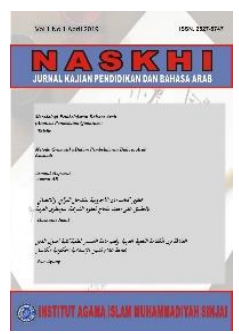

\title{
NASKHI
}

\author{
Jurnal Kajian Pendidikan dan Bahasa Arab \\ Volume 2, No. 1, 2020 \\ ISSN (print) : 2527-5747 \\ ISSN (online) : 2716-3369 \\ Homepage : https://journal.iaimsinjai.ac.id/index.php/naskhi
}

belajar dan mengajar ini tidak bisa diawali oleh sikap terpaksa untuk mengikuti sebuah struktur kurikulum sehingga memasung kebebasan berkreasi untuk memperoleh pengetahuan dan menajamkan keterampilan. Belajar sejatinya memberdayakan aspek fisik dan psikis manusia agar menjadi pribadi unggul yang efektif.

Berbagai keluhan tentang rendahnya prestasi pembelajaran bahasa Arab acap kita dengar dari beragam penelitian dan tulisan. Usaha untuk memperbaiki mutu pembelajaran pun telah dilakukan dengan berbagai upaya. Namun, hasilnya tetap saja masih jauh dari memadai. Karena itu, ada baiknya diidentifikasi kembali problematika pembelajaran bahasa Arab disertai upaya untuk mencari solusi yang tepat. Tulisan ini akan memetakan problematika dan solusi pembelajaran bahasa Arab secara akademik dan pedagogik.

\section{PEMBAHASAN}

\section{Problematika Pengajaran Bahasa Arab}

Secara teoretis, ada dua problem yang sedang dan akan terus dihadapi pembelajaran bahasa Arab, yaitu: problem kebahasaan yang sering disebut problem linguistik, dan problem non-kebahasaan atau non-linguistik. Pengetahuan guru tentang kedua problem itu sangat penting agar ia dapat meminimalisasi problem dan mencari solusinya yang tepat sehingga pembelajaran bahasa Arab dalam batas minimal dapat tercapai dengan baik. Sikap mengeluh tanpa mencari jalan keluar adalah hal utopis.

Problem kebahasaan adalah persoalanpersoalan yang dihadapi siswa atau pembelajar (pengajar) yang terkait langsung dengan bahasa. Sedangkan, problem nonkebahasaan adalah persoalan-persoalan yang turut mempengaruhi, bahkan dominan bisa menggagalkan, kesuksesan program pembelajaran yang dilaksanakan. $^{1}$

Problem kebahasaan dapat diidentifikasi, antara lain, sebagai berikut:

\section{Problem Ashwât 'Arabiyyah}

Problem ashwât adalah persoalan terkait dengan sistem bunyi atau fonologi. Bunyi bahasa Arab ada yang memiliki kedekatan dengan bunyi bahasa pebelajar dan ada pula yang tidak memiliki padanan dalam bahasa pebelajar. Secara teori, bunyi yang tidak memiliki padanan dalam bahasa pebelajar diduga akan banyak menyulitkan pebelajar daripada bunyi yang mempunyai padanan. Karena itu, solusinya adalah memberikan pola latihan intens dan contoh penuturan dari kata atau kalimat yang beragam².

Dalam hal ini, guru dituntut memiliki keterampilan ekspresif dalam member contoh sebanyak mungkin agar pengayaan kosakata juga terbangun secara baik dan membentuk kumulatif. Ini berarti pemilihan contoh juga harus berupa kosakata yang mempunyai kebermaknaan.

${ }^{1}$ Aziz Fahrurrozi dan Erta Mahyudin, Pembelajaran Bahasa Asing (Jakarta: Bania Publishing, 2010), h. 1.

${ }^{2}$ Muhammad 'Ali al-Khûlî, Asâlîb Tadrîs al- Lughah al- 'Arabiyyah (Riyadh: Maktabah al-Farazdaq, 1989), h. 147. 


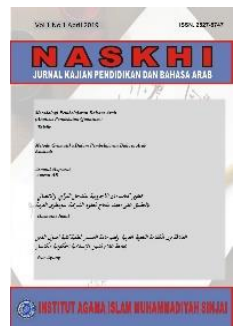

NASKHI

Jurnal Kajian Pendidikan dan Bahasa Arab

Volume 2, No. 1, 2020

ISSN (print) : 2527-5747

ISSN (online) : 2716-3369

Homepage : https://journal.iaimsinjai.ac.id/index.php/naskhi

\section{Problem Kosakata (Mufradât)}

Bahasa Arab adalah bahasa yang pola pembentukan katanya sangat beragam dan fleksibel, baik melalui cara derivasi (tashrîf isytiqâqî) maupun dengan cara infleksi (tashrîf i'râbî). Melalui dua cara pembentukan kata ini, bahasa Arab menjadi sangat kaya dengan kosakata (mufradât). Dalam konteks penguasaan kosakata, Rusydi Ahmad Thu'aimah berpendapat: "Seseorang tidak akan dapat menguasai bahasa sebelum ia menguasai kosakata bahasa tersebut"3.

Dengan karakter bahasa Arab yang pembentukan katanya beragam dan ?leksibel tersebut, problem pengajaran kosakata bahasa Arab akan terletak pada keanekaragaman bentuk marfologis (wazan) dan makna yang dikandungnya, serta akan terkait dengan konsepkonsep perubahan derivasi, perubahanin?leksi, kata kerja (af'âl/verb), mufrad (singular), mutsannâ (dual), jamak (plural), ta'nîts (feminine), tadzkîr (masculine), serta makna leksikal dan fungsional.

Dalam konteks pengajaran bahasa, ada realita lain yang terkait dengan kosakata yang perlu diperhatikan, yaitu banyaknya kata dan istilah Arab yang telah diserap ke dalam kosakata bahasa Indonesia atau bahasa daerah. Pada satu sisi, kondisi tersebut memberi banyak keuntungan, tetapi pada saat yang sama, perpindahan dan penyerapan kata-kata bahasa Arab ke bahasa Indonesia itu dapat juga menimbulkan problem tersendiri, antara lain:

\section{a. Penggeseran arti kata serapan}

Banyak kata atau ungkapan yang diserap dalam bahasa Indonesia artinya berubah dari arti sebenarnya dalam bahasa Arab. Contohnya, ungkapan "لهاء " ما شấ (mâ syâ'a Allâh). Dalam bahasa Arab, "mâ syâ'a Allâh" digunakan untuk menunjukkan rasa takjub (terhadap hal-hal yang indah dan luar biasa) tetapi dalam bahasa Indonesia, maknanya berubah untuk menunjukkan hal-hal yang bernuansa negatif atau keluhan, seperti ungkapan "Masya-Allah... anak ini kok bandel amat!"

\section{b. Perubahan lafal dari bunyi bahasa Arabnya}

Contohnya, kata "berkat" yang berasal dari kata بركة (barakah) dan kata "kabar" yang berasal dari kata (khabar).

\section{c. Perubahan arti tetapi lafalnya tidak berubah}

Misalnya, kata "kalimat" berasal dari kata كلمة (kalimah/t). Dalam bahasa Arab, kalimah/t berarti "kata" tetapi dalam bahasa Indonesia, ia berubah artinya menjadi "susunan kata yang lengkap maknanya". Padahal, susunan kata dalam bahasa Arab disebut تركيب (tarkîb) atau جملة (jumlah). Begitu juga dengan beberapa kata dan istilah yang telah mengalami penyempitan dan perluasan makna.

Selanjutnya, menurut mazhab struktural, kata adalah suatu wujud minimal yang bebas. Kata adalah unit terkecil dari suatu bahasa yang bersifat independen ${ }^{4}$. Takrif kata atau mufradât sangat beragam sesuai dengan pandangan para pakar terhadapnya. Karena itu, pembelajar sebaiknya memahami hakikat pengajaran mufradât sehingga terhindar dari kesalahan bunyi dan arti, serta pergeseran makna.

\footnotetext{
${ }^{3}$ Rusydî Ahmad Thu'aimah, Ta'lîm al-'Arabiyah li Ghair-al-Nâthiqîna bihâ: Manâhijuhâ wa asâlîbuhâ (Rabath: Isesco, 1989), h. 194.

${ }^{4}$ Abdul Chaer, Psikolinguistik Kajian Teoretik (Jakarta: Rineka Cipta, 2003), h. 163.
} 


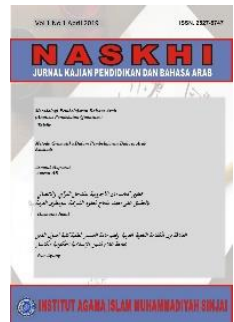

NASKHI

Jurnal Kajian Pendidikan dan Bahasa Arab

Volume 2, No. 1, 2020

ISSN (print) : 2527-5747

ISSN (online) : 2716-3369

Homepage : https://journal.iaimsinjai.ac.id/index.php/naskhi

\section{Problem $Q \overline{a w a}$ ' $i d$ dan I trâb}

Tata bahasa Arab atau qawâ'id, baik terkait pembentukan kata (shar'iyyah) maupun susunan kalimat (nahwiyyah), sering kali dianggap kendala besar bagi pelajar bahasa Arab. Apa pun anggapan kita terhadap kesulitan qawâ 'id itu tidak akan mengubah eksistensinya.

Sebab, guru pada akhirnya tetap dituntut memahami apa yang dirasakan sulit oleh pebelajar bahasa Arab, lalu menawarkan cara yang mudah untuk menguasai bahasa Arab dalam waktu relatif singkat. Menurut penulis, upaya yang harus dilakukan adalah menyederhanakan dua hal, yaitu binyah al-kalimah (bentuk kata) dan mawâqi 'al-i 'râb (fungsi kata dalam kalimat). Penyederhanaan dimaksud adalah menghindari dan bahkan membuang hal-hal yang kurang fungsional atau yang frekuensi penggunaannya sangat jarang. Binyah al-kalimah (konstruk kata) yang dipilih adalah yang fungsionalnya baik dalam bahasa lisan atau membaca teks.

Fakta menunjukkan bahwa di antara wazan-wazan (neraca/pola kata) yang diperkenalkan dalam pembelajaran bahasa Arab_-kecuali fi'il dan mashdar yang bersumber pada kata dasar tiga huruf-banyak yang tidak produktif untuk kepentingan berbahasa dan hanya membangun cara belajar dengan pendekatan hafalan. Padahal, pembelajaran kaidah menurut hemat penulis seharusnya dibelajarkan dengan pendekatan analogi atau qiyâsî dan bukan dengan pendekatan samâ $\hat{\imath}$ (mengikuti tuturan pemilik bahasa). Menurut al-Ghalayaini, ilmu sharf sebagai bagian dari gramatika yang berbicara tentang dasar-dasar pembentukan kata harus mendapat perhatian dalam pembelajaran bahasa ${ }^{5}$.

\section{Problem Tarâkîb (Struktur Kalimat)}

Problem tarâkîb (struktur kalimat) merupakan salah satu masalah kebahasaan yang sering dihadapi oleh pembelajar dan pelajar bahasa Arab. Masalah ini dapat diatasi dengan memberikan pola kalimat ismiyyah dan fi liyah yang frekuensinya tinggi, dengan keragaman bentuk dan modelnya, lalu melatihkannya dengan pola pengembangan yang beragam. Inilah di antara problem linguistik yang akan selalu dihadapi oleh guru bahasa Arab. Adapun problem non kebahasaan (nonlinguistik), antara lain, meliputi:

a. Motivasi dan minat belajar

Motivasi dan minat belajar merupakan problem non-linguistik yang banyak dijumpai di kelas-kelas pembelajaran bahasa Arab, dan pencapaian hasil belajar sering kali dipengaruhi oleh motivasi dan minat belajar ${ }^{6}$. Belajar tanpa motivasi tidak dapat mencapai hasil yang maksimal, apalagi jika dalam diri orang yang belajar tertanam perasaan tidak suka terhadap materi pelajaran dan guru yang mengajarkannya. Belajar yang sukses adalah yang melibatkan siswa secara untuh, baik fisik maupun psikis. Oleh karena itu, guru harus

${ }^{5}$ Musthafa al-Ghalayaini, Jâmi ' al-Durûsal-'Arabiyyah (Beirut: al-Maktabah al'Ashriyyah, 2003), h. 9.

${ }^{6}$ Para pakar motivasi, seperti Maslow dengan teorinya: hierarki kebutuhan, McClelland dengan "motivasi berprestasi", Mc Gregor (teori X dan Y), juga teori motivasi Hezberg, dan teori ERG Aldefer, sama-sama meyakini bahwa keberhasilan belajar dipengaruhi oleh motivasi dan kebutuhan atau keinginan kuat untuk berprestasi. 


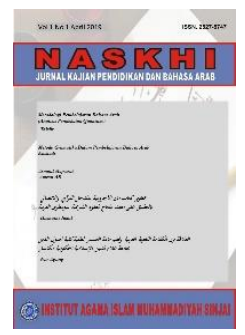

NASKHI

Jurnal Kajian Pendidikan dan Bahasa Arab

Volume 2, No. 1, 2020

ISSN (print) : 2527-5747

ISSN (online) : 2716-3369

Homepage : https://journal.iaimsinjai.ac.id/index.php/naskhi

mendorong siswa untuk menyukai bahasa Arab yang akan berguna bagi kehidupannya kelak.

b. Sarana belajar

Sarana belajar dapat menjadi problem apabila tidak kondusif, seperti kondisi yang bising, panas, dan tidak nyaman. Sarana yang tidak kondusif akan memperburuk pencapaian hasil belajar bahasa Arab. Sebaliknya, suasana yang menyenangkan dan membuat siswa betah berada di ruang belajar akan mendukung pencapaian hasil belajar yang maksimal.

c. Kompetensi guru

Guru yang tidak kompeten akan menjadi problem dalam pembelajaran bahasa Arab. Kompetensi guru dinilai dari segi profesional, pedagogik, kepribadian, dan sosial. Masalahnya, banyak guru bahasa tidak berlatar pendidikan guru bahasa, tetapi sekadar mengetahui bahasa Arab.

d. Metode pembelajaran yang digunakan(dipilih secara tepat sesuai tujuan, sesuai materi, sesuai sarana tersedia dan tingkat kemampuan pembelajar). Ketidak tepatan memilih metode apalagi tidak tahu metode apa yang harus dipilih tentu sangat mempengaruhi terhadap keberhasilan belajar mengajar.

e. Waktu yang tersedia (cukup waktu untuk mendapat layanan, baik di kelas maupun di luar kelas).

f. Lingkungan berbahasa (yang dapat mendorong siswa berani berbicara tanpa ada rasa malu dan takut salah). Makin tinggi rasa malu dan takut salah, makin tidak akan pernah tercipta suasana berbahasa. Dari kedua problem di atas, tampak bahwa yang paling dominan mempengaruhi keberhasilan pembelajaran bahasa Arab adalah problem-problem non-kebahasaan, salah satunya adalah metode. Hal lain yang tidak kalah penting dari problem nonlinguistik adalah motivasi belajar siswa. Sebab, belajar bahasa dengan hanya mengandalkan waktu yang tersedia di kelas dapat dipastikan tidak akan sukses kecuali hanya untuk memenuhi kriteria ketuntasan minimal rapor.

\section{Kunci Pembelajaran Bahasa Asing}

Ada tiga kata kunci yang perlu dipahami dengan baik terkait dengan pembelajaran bahasa Arab sebagai bahasa asing, yaitu: pendekatan (al-madkhal), metode (altharîqah), teknik (al-uslûb al-ijrâ'î).

\section{Pendekatan (Madkhal/Approach)}

Pendekatan adalah sejumlah asumsi yang berkaitan dengan sifat alami bahasa, sifat alami pengajaran bahasa, dan pembelajarannya. Pendekatan berbentuk asumsi-asumsi dan konsep tentang bahasa, pembelajaran bahasa, dan pengajaran bahasa. Orang-orang bisa berbeda pendapat tentang suatu asumsi. Oleh karena itu, dalam pengajaran bahasa juga ditemukan berbagai asumsi yang berbeda tentang hakikat bahasa dan pengajarannya. Dari asumsi-asumsi tentang bahasa dan pembelajaran bahasa, suatu metode akan dikembangkan, dan bisa jadi beberapa metode dilahirkan dari satu pendekatan yang sama.

Richards dan Rodgers menyatakan bahwa paling tidak ada tiga aliran pandangan yang berbeda tentang sifat alami bahasa, yakni: aliran struktural, aliran fungsional, dan aliran interaksional. Aliran struktural melihat bahasa sebagai 


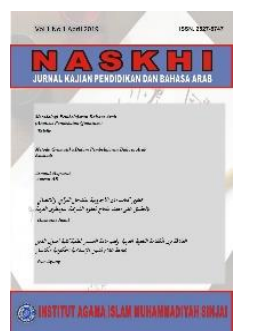

\section{NASKHI}

\section{Jurnal Kajian Pendidikan dan Bahasa Arab}

Volume 2, No. 1, 2020

ISSN (print) : 2527-5747

ISSN (online) : 2716-3369

Homepage : https://journal.iaimsinjai.ac.id/index.php/naskhi

suatu sistem yang terbentuk dari beberapa elemen/unsure yang berhubungan secara struktural. Aliran fungsional menganggap bahasa sebagai suatu alat (media) untuk mengungkapkan makna-makna fungsional. Aliran ini menekankan tidak hanya pada elemen-eleman tata bahasa (seperti aliran struktural) tetapi juga seputar topik-topik atau konsep-konsep yang ingin dikomunikasikan oleh para pebelajar bahasa. Adapun aliran interaksional memandang bahwa bahasa adalah suatu sarana (media) untuk menciptakan hubungan-hubungan interpersonal dan interaksi-interaksi sosial antar individu ${ }^{7}$. Ketiga pandangan yang berbeda tentang sifat alami bahasa tersebut akan mengarahkan masingmasing orang memiliki asumsi-asumsi yang berbeda tentang apa itu bahasa dan pada akhirnya melahirkan beragam metode dalam pengajaran bahasa.

Sebagai contoh, metode-metode pengajaran bahasa yang telah dikembangkan berdasarkan aliran struktural menyarankan para guru bahasa untuk memilih bahan-bahan pengajaran mereka berdasarkan pertimbangan yang bersifat tata bahasa. Mereka memilih unsur-unsur tata bahasa lalu menyajikannya dalam suatu urutan dalam keseluruhan rencana pengajaran mereka. Evaluasi pembelajaran dan proses pembelajaran juga didasarkan pada hal-hal yang bersifat ketatabahasaan. Karena itu, materi evaluasinya diorientasikan secara gramatikal. Begitu juga halnya dengan metode lain yang dikembangkan berdasarkan dua aliran tentang sifat alami bahasa.

Metode-metode yang berbeda berasal dari teori-teori atau asumsiasumsi yang berbeda tentang sifat alami bahasa. Asumsi-asumsi tentang sifat alami bahasa bisa berbeda karena berbeda orang bisa menyepakati asumsiasumsi tertentu sementara beberapa orang lain bisa menyepakati asumsiasumsi yang lain. Mereka tidak harus saling membantah mengapa sebagian dari orang menyepakati asumsi-asumsi yang mereka tidak setujui. Asumsiasumsi di bawah ini merupakan asumsiasumsi yang umum seputar sifat alami bahasa.

a. Bahasa adalah sekumpulan bunyi yang memiliki maksud tertentu dan diorganisir oleh aturan-aturan tata bahasa (Metode Guru Diam).

b. Bahasa adalah ungkapan percakapan sehari-hari dari kebanyakan orang yang diucapkan dengan kecepatan normal (Metode Audiolingual).

c. Bahasa adalah suatu sistem untuk mengungkapkan maksud (Metode Komunikatif).

d. Bahasa adalah seperangkat aturan tata bahasa dan bahasa terdiri dari bagian-bagian kecil bahasa (Metode Respons Fisik Total) ${ }^{8}$.

Selanjutnya, prinsip-prinsip dalam pengajaran bahasa asing dikembangkan dari satu aksioma tentang bahasa. Penulis melihat bahwa prinsip-prinsip berikut dikembangkan dari satu aksioma bahwa bahasa adalah sekumpulan bunyi yang memiliki maksud tertentu dan diorganisir oleh aturan-aturan tata bahasa.

a. Silabus tersusun dari strukturstruktur linguistik.

\footnotetext{
${ }^{7}$ Richards dan Rodgers, Approaches and Methods in Language Teaching (Cambridge: Cambridge University Press, 2001), h. 20-21.

${ }^{8}$ Aziz Fahrurrozi dan Erta Mahyudin, op. cit., h. 3.
} 


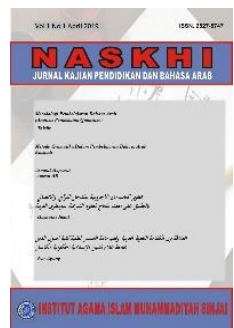

NASKHI

Jurnal Kajian Pendidikan dan Bahasa Arab

Volume 2, No. 1, 2020

ISSN (print) : 2527-5747

ISSN (online) : 2716-3369

Homepage : https://journal.iaimsinjai.ac.id/index.php/naskhi

b. Bahasa pada tahapan awal dipelajari sebagai bunyi lalu dikaitkan dengan makna.

c. Pengulangan bahan pengajaran didasarkan pada struktur-struktur linguistik.

Ketiga prinsip di atas menyiratkan bahwa pengajaran bahasa harus dilakukan dengan suatu silabus yang diatur berdasarkan sudut pandang tata bahasa. Penyajian bahan-bahan ajar dalam pengajaran bahasa tidak selalu dilakukan dengan cara demikian. Dalam menyampaikan bahan ajar, ada beberapa jenis silabus yang dikembangkan dari asumsi-asumsi yang berbeda tentang sifat alami bahasa, dan masing-masing jenis silabus akan menjadi karakter pembeda suatu metode.

Mencermati bahwa pendekatan juga terkait dengan asumsi-asumsi tentang pengajaran dan pembelajaran bahasa, maka asumsi-asumsi tentang sifat alami bahasa perlu didukung oleh teori-teori tentang pembelajaran. Ada banyak teori tentang pembelajaran. Richards dan Rodgers menyatakan bahwa suatu landasan teori pembelajaran yang berhubungan dengan pendekatan atau metode terkait dengan dua pertanyaan mendasar, yaitu: (1) apa saja proses psikolinguistik dan kognitif yang dilibatkan dalam pembelajaran bahasa, (2) apa saja kondisi yang harus dipenuhi demi terlaksananya proses pembelajaran tersebut ${ }^{9}$.

Secara umum, sebuah pendekatan mempunyai jawaban untuk kedua pertanyaan tersebut tetapi bisa juga hanya menekankan pada salah satu dari dua pertanyaan itu. Beberapa contoh asumsi yang berhubungan dengan teori-teori pembelajaran adalah sebagai berikut.

a. Pembelajaran akan lebih mudah manakala para pebelajar bahasa menemukan sendiri dibandingkan dengan melalui pengulangan dan hafalan yang tidak dibarengi pemahaman tentang apa yang dipebelajarinya (Metode Guru Diam).

b. Pembelajaran melibatkan fungsifungsi tak-sadar, sebagaimana juga melibatkan fungsi-fungsi sadar (Metode Suggestopedia).

c. Norma-norma dalam masyarakat sering kali menghalangi proses pembelajaran (Metode Suggestopedia).

d. Pembelajaran bahasa akan berlangsung jika para pebelajar bahasa mempunyai rasa aman (Metode Pembelajaran Bahasa Berkelompok).

e. Pembelajaran bahasa adalah suatu proses pembentukan kebiasaan (Metode Audiolingual).

Lalu, bagaimana suatu asumsi tentang pembelajaran bahasa berkembang menjadi prinsip-prinsip suatu metode? Hal ini dapat dijelaskan dengan ilustrasi berikut. Ketika guru bahasa mempunyai asumsi bahwa 'Pembelajaran akan lebih mudah jika para pebelajar bahasa menemukan sendiri dibandingkan dengan melalui pengulangan dan hafalan yang tidak dibarengi pemahaman', maka ia akan segera mengembangkan prinsipprinsip yang sesuai dengan penemuan sendiri oleh pebelajar. Di antara prinsip tersebut adalah:

a. Bahasa diajarkan dengan menggunakan objek fisik (benda nyata).

${ }^{9}$ Richards dan Rodgers, op. cit., h. 22. 


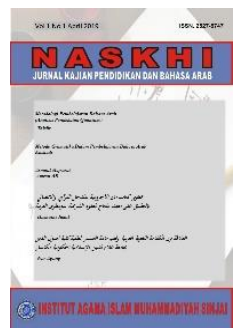

NASKHI

Jurnal Kajian Pendidikan dan Bahasa Arab

Volume 2, No. 1, 2020

ISSN (print) : 2527-5747

ISSN (online) : 2716-3369

Homepage : https://journal.iaimsinjai.ac.id/index.php/naskhi

b. Bahasa disajikan melalui pemecahan masalah (problem solving) yang melibatkan materi ajar yang dipelajari.

c. Makna dijelaskan melalui penyajian berbagai konteks, bukan melalui terjemahan.

d. Para siswa diberi kesempatan untuk melakukan banyak praktik tanpa menekankan pengulangan.

Asumsi tentang pembelajaran bahasa yang telah dikembangkan ke dalam empat prinsip tersebut masih bisa berkembang menjadi prinsipprinsip lain bergantung pada kreativitas dan pengalaman guru.

\section{Metode (Tharîqah/Method)}

Pendekatan berada pada level teoretis, sementara metode adalah rencana dari pengajaran bahasa yang konsisten dengan suatu pendekatan. Metode menjadi kelanjutan pendekatan karena rencana dari pengajaran bahasa harus dikembangkan dari teoriteori tentang sifat alami bahasa dan pembelajaran bahasa. Perbedaan makna dari "metode" dapat dirujuk dari nama beberapa metode. Kata "metode" dalam Metode Langsung mengacu kepada suatu aspek dari pengajaran bahasa: yaitu penyajian materi. Kata "metode" dalam Metode Membaca mengacu pada penekanan dari suatu keterampilan berbahasa: yaitu keterampilan membaca. Sedangkan, dalam Metode Tata Bahasa- Terjemah, kata "metode" menekankan pada aspek materi pengajaran, yaitu tata bahasa dan terjemah ${ }^{10}$.

Menurut Mackey, semua pengajaran, apakah yang baik atau jelek, akan melibatkan pemilihan (ikhtiyâr/selection), penjenjangan (tadarruj/ gradation), penyajian (taqdîm/presentaion), dan pengulangan (tikrâr/repetition) $)^{11}$.

Pembelajaran melibatkan pemilihan karena guru bahasa tidak bisa mengajarkan keseluruhan aspek bahasa. Guru harus memilih bagian yang ingin dia ajar. Pengajaran juga harus melibatkan gradasi materi karena guru tidak bisa mengajar semua yang telah dia pilih secara serempak dan harus meletakkan yang satu setelah yang lain. Pembelajaran juga terkait dengan presentasi karena guru tidak bisa mengajar bahasa tanpa mengkomunikasikannya kepada siswa; guru harus menyajikan apa yang telah dia pilih kepada siswa. Dan, pembelajaran juga terkait dengan pengulangan karena guru tidak bisa membuat siswa belajar bahasa tanpa pengulangan bahan-bahan yang sedang mereka pelajari; guru harus mengajarkan ragam keterampilan berbahasa dengan praktik; dan semua keterampilan bergantung pada praktik. Oleh karena itu, semua metode perlu mermasukkan empat langkah pengajaran tersebut. Ada cara lain untuk memahami makna metode dalam pengajaran bahasa, yaitu yang diusulkan oleh Richards dan Rodgers ${ }^{12}$. Mereka mereformasi konsep 'metode' dan memberikan penamaan baru untuk "pendekatan, metode, dan teknik" menjadi "pendekatan, rancangan, dan prosedur". Dalam konsep baru ini, metode menjadi istilah kunci untuk

\footnotetext{
${ }^{10}$ A. Fuad Efendy, Metodologi Pengajaran Bahasa Arab (Malang: Misykat, 2005), h. 35.

${ }^{11}$ W. F. Mackey, Language Teaching Analysis

(London: Longman, 1965), h. 157.

${ }^{12}$ Lihat H. Douglas Brown, Teaching by Principles: An Interactive Approach to Language Pedagogy (New York: Pearson-Longman, 2001).
} 


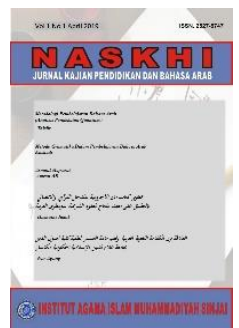

NASKHI

Jurnal Kajian Pendidikan dan Bahasa Arab

Volume 2, No. 1, 2020

ISSN (print) : 2527-5747

ISSN (online) : 2716-3369

Homepage : https://journal.iaimsinjai.ac.id/index.php/naskhi

menggambarkan ketiga tahapan proses (pendekatan, desain, dan prosedur) tersebut, atau menjadi payung utama untuk spesifikasi dan interrelasi antara teori dan praktik. Sebuah metode secara teoretis terkait dengan suatu pendekatan dan diorganisir dalam desain, dan secara praktis direalisasikan dalam prosedur. Pada tingkat desain, sasaran hasil dari pengajaran bahasa, silabus bahasa dan isi ditentukan. Pada tingkat ini pula, peran dari guru dan materi pembelajaran ditetapkan. Dengan menggunakan terminologi Richards dan Rodgers, metode mencakup pendekatan, desain dan prosedur. Meskipun uraian Richards dan Rodgers tentang metode berbeda dengan konsep Anthony, pada dasarnya keduanya bersifat sebangun, yaitu sama-sama memahami bahwa suatu metode didasarkan pada beberapa asumsi tentang bahasa dan pembelajaran bahasa, dan selanjutnya akan direalisasikan dalam suatu rangkaian teknik penyajian bahan ajar kepada para pebelajar bahasa, yang sering disebut prosedur.

Dalam kaitan pengembangan suatu pendekatan menjadi suatu metode, perlu dipahami makna desain sistem pembelajaran. Desain berada pada tingkat analisis metode yang mempertimbangkan; (a) apa sasaran akhir dari suatu metode; (b) bagaimana isi bahasa dipilih dan diorganisir dalam suatu metode, model silabus yang digunakan suatu metode; (c) jenis-jenis tugas dan aktivitas pembelajaran yang didukung suatu metode; (d) peranperan dari para guru bahasa; (e) peranperan dari para pebelajar bahasa; dan (f) peran bahan ajar.

Hamadah berpendapat bahwa penggunaan bahasa langsung dalam pengajaran bahasa asing akan efektif untuk tercaapainya kemahiran berbahasa. Namun, ada juga metode lain yang memberikan penekanan yang lebih besar pada tata bahasa dan pengucapan kata-kata yang akurat sejak dini. Ada beberapa metode yang dikembangkan untuk mengajar tata bahasa dan kosakata dasar suatu bahasa. Yang lain lagi lebih memilih sasaran akhir dalam bentuk pemahaman kebahasaan disbanding dalam bentuk perilaku berbahasa ${ }^{13}$. Di lain pihak, Bambang berpendapat bahwa metode tata bahasa-terjemah yang pernah mendominasi pengajaran bahasa asing pada tahun 1840-an masih dapat diandalkan dalam pengajaran tata bahasa ${ }^{14}$. Begitulah beberapa perbedaan tujuan akhir metode pengajaran bahasa yang dikembangkan dari asumsi tentang bahasa dan pembelajaran bahasa yang berbeda-beda pula.

Menimbang bahwa metode juga dikembangkan dari satu asumsi tentang sifat alami bahasa, maka metode juga akan berhubungan dengan pemilihan materi pengajaran, yang sering disebut dengan silabus. Silabus bahasa akan menjadi pemandu bagi para guru bahasa dalam memutuskan apa yang harus diajarkan (pemilihan), urutan materi ketika diajarkan (gradasi), bagaimana makna atau bentuk-bentuk bahasa disampaikan (presentasi), dan apa yang harus dilaksanakan demi tercapainya penguasaan terhadap suatu bahasa (pengulangan).

\footnotetext{
${ }^{13}$ Hamadah Ibrahim, al-Ittijâhât al-Mu 'âshirah fî Tadrîs al-Lughah al- 'Arabiyyah wa alLughah al-Hayyah al-Ukhrâ li Ghair al-Nâthiqîna bihâ (Kairo: Dâr al-Fikr al-Arabî, 1987), h. 50 .

${ }^{14}$ Bambang Kaswanti Purwo, Pragmatik dan Pengajaran Bahasa: Menyibak Kurikulum 1984 (Yogyakarta: Kanisius, 1990), h. 43.
} 


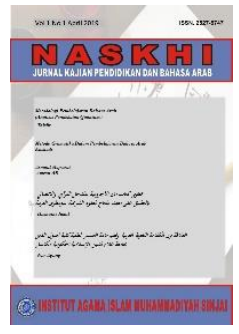

NASKHI

Jurnal Kajian Pendidikan dan Bahasa Arab

Volume 2, No. 1, 2020

ISSN (print) : 2527-5747

ISSN (online) : 2716-3369

Homepage : https://journal.iaimsinjai.ac.id/index.php/naskhi

Karena silabus bahasa mempunyai peranan penting dalam memahami metode pembelajaran, diperlukan kejelasan tentang jenis-jenis dari silabus bahasa. Guru bahasa sudah seharusnya memahami enam jenis silabus pengajaran bahasa dan mampu memilih silabus apa yang menjadi acuan pengajarannya. Namun, dalam praktiknya, akan ada kombinasi antara dua jenis atau lebih dari silabus. Pemilihan jenis silabus bergantung pada metode, yang dikembangkan berdasarkan pada suatu asumsi tentang sifat alami bahasa dan pembelajaran bahasa.

Enam jenis pengajaran bahasa silabus adalah sebagai berikut:

a. Silabus Struktural

Materi pengajaran bahasa berisi sekumpulan bentuk dan struktur bahasa yang sedang diajarkan. Contohnya: kata benda, kata kerja, kata sifat, pernyataan, pertanyaan, anak kalimat, dan seterusnya.

b. Silabus Nosional/Fungsional

Materi pengajaran bahasa berisi serangkaian fungsi atau maksud yang diungkapkan ketika suatu bahasa digunakan. Silabus nosional bisa meliputi fungsi-fungsi bahasa, seperti ungkapan salam, minta maaf, meminta, dan memberi tahu, serta bisa termasuk gagasan bahasa, seperti usia, warna, perbandingan dan waktu.

c. Silabus Situational

Materi pengajaran bahasa berisi sekumpulan situasi imajiner yang menempatkan suatu bahasa digunakan sesuai momen tertentu. Silabus situational, misalnya, bias berisi situasi di rumah makan, di sekolah, di kantor, forum dialog, seminar, bertemu dengan tetangga baru, dan berobat ke dokter.

d. Silabus Berbasis Keterampilan

Materi pengajaran bahasa berisi sejumlah keterampilan yang spesi $\square \mathrm{ik}$ dalam menggunakan bahasa sasaran. Contoh dari keterampilanketerampilan dalam menggunakan bahasa sasaran bisa berupa membaca untuk menemukan gagasan utama, menulis alinea-alinea yang baik, dan mendengarkan untuk menemukan gagasan utama.

e. Silabus Berbasis Tugas

Isi dari pengajaran bahasa dengan silabus jenis ini adalah serangkaian tugas terstruktur yang harus dikerjakan oleh para pebelajar bahasa; tugas-tugas tersebut merupakan berbagai aktivitas yang diperlukan ketika menggunakan bahasa sasaran. Contoh dari tugastugas tersebut adalah melamar pekerjaan, memesan makanan via telepon, dan mendapatkan informasi tentang suatu tempat melalui telepon.

f. Silabus Berbasis Isi

Materi silabus berbasis isi dalam pengajaran bahasa sebenarnya bukan silabus bahasa. Tujuan utama penggunaan silabus ini adalah untuk mengajar beberapa hal atau informasi dengan menggunakan bahasa sasaran. Karena itu, pokok bahasan menjadi bagian primer, sedangkan pembelajaran bahasa terjadi secara otomatis selagi para pebelajar bahasa sedang mempelajari pokok materi. Contoh dari suatu silabus yang berbasis isi adalah suatu kelas Filsafat Islam yang diajar dengan bahasa Arab. 


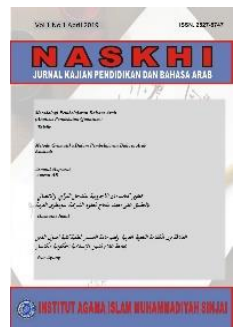

NASKHI

Jurnal Kajian Pendidikan dan Bahasa Arab

Volume 2, No. 1, 2020

ISSN (print) : 2527-5747

ISSN (online) : 2716-3369

Homepage : https://journal.iaimsinjai.ac.id/index.php/naskhi

Selanjutnya, sasaran akhir dari suatu metode dicapai melalui proses pembelajaran, melalui interaksi yang mengarahkan dan menata kegiatan para guru, para siswa, dan bahan ajar di dalam kelas. Perbedaan antarmetode pada tingkat pendekatan menjelma dalam pemilihan aktivitas pembelajaran di dalam kelas. Proses pembelajaran yang berfokus pada ketelitian tata bahasa akan sangat berbeda dari pembelajaran yang berfokus kepada keterampilanketerampilan komunikatif. Aktivitas yang dirancang untuk pengembangan proses-proses psikolinguistik yang spesi $\square$ ik dalam pemerolehan bahasa akan berbeda dengan aktivitas yang diarahkan kepada penguasaan polapola tata bahasa tertentu. Metode Audiolingual, sebagai contoh, menggunakan tanya jawab dan drill pola-pola bahasa secara ekstensif. Dalam metode ini, game-game interaktif sering digunakan untuk motivasi dan untuk memberikan kesempatan melepaskandiri dari kejenuhan.

Di lain pihak, drill-drill pola bahasa Metode Guru Diam juga menggunakan aktivitas pemecahan masalah yang melibatkan pemakaian baganbagan khusus dan balok-balok warna-warnai. Berbeda dengan itu, para penjunjung pengajaran bahasa komunikatif menganjurkan pemakaian tugas-tugas yang melibatkan sebuah "sumbatan informasi" dan "transfer informasi"; dalam hal ini, para pebelajar mengerjakan tugas yang sama tetapi masing-masing pebelajar mempunyai informasi yang berbeda yang diperlukan untuk melengkapi tugas tersebut. Jenis-jenis aktivitas pembelajaran dalam metode dengan demikian menggambarkan tentang kegiatankegiatan utama yang didukung dalam aktivitas pembelajaran, seperti Tanya jawab, menanggapi perintah, pemecahan masalah kelompok, aktivitas pertukaran informasi, improvisasi, tanya jawab, atau latihanlatihan dan drill-drill.

Di samping menentukan tujuan akhir, jenis silabus bahasa, dan jenisjenis tugas dan aktivitas pembelajaran bahasa, asumsi-asumsi tentang bahasa dan pembelajaran bahasa (pendekatan) juga menentukan peran-peran dari para guru bahasa dan para pebelajar bahasa. Pada dasarnya, para guru bahasa mempunyai dua fungsi utama: yaitu fungsi instruksional dan fungsi manajerial. ${ }^{15}$ Kedua fungsi tersebut saling melengkapi satu dengan yang lainnya; fungsi pertama tidak akan terlaksana tanpa fungsi kedua. Dalam praktiknya, sulit untuk memisahkan kedua fungsi tersebut. Dan, para guru bahasa dapat melaksanakan kedua fungsi tersebut secara serempak.

Beberapa metode lebih menekankan pelaksanaan fungsi instruksional daripada manajerial, sementara beberapa metode lain mendorong para guru bahasa untuk berfungsi lebih banyak sebagai manajer kelas. Dalam beberapa metode, peran dari seorang guru bahasa sangat dominan sementara dalam beberapa metode yang lain, peran guru kurang dominan dalam strategi pembelajaran. Seperti yang dinyatakan dalam Richards dan Rodgers, beberapa metode sepenuhnya bergantung pada guru sebagai seorang sumber pengetahuan

\footnotetext{
${ }^{15}$ Tony Wright, Role of Teacher and Learner (Oxford: Oxford University Press, 1987),
} h. 52 . 


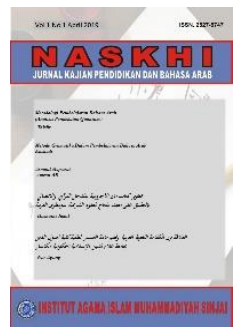

NASKHI

Jurnal Kajian Pendidikan dan Bahasa Arab

Volume 2, No. 1, 2020

ISSN (print) : 2527-5747

ISSN (online) : 2716-3369

Homepage : https://journal.iaimsinjai.ac.id/index.php/naskhi

dan penentu arah pembelajaran; sementara beberapa metode lain melihat guru berperan sebagai katalisator, konsultan, pemandu, dan model untuk belajar ${ }^{16}$.

Beberapa peran paling umum yang dimainkan oleh para guru bahasa dengan menggunakan metode yang berbeda dapat diuraikan sebagai berikut.

a. Guru bahasa berfungsi sebagai seorang organisator di dalam kelas. Guru menjaga kedisiplinan agar tercipta suasana pembelajaran yang efektif. Fungsi ini bisa dijalankan dengan melibatkan para pebelajar lebih aktif di dalam aktivitas kelas yang menuntut komunikasi intersiswa dan usaha-usaha menuntut kerja sama.

b. Guru bahasa berfungsi sebagai seorang konselor. Peran guru adalah untuk menanggapi berbagai permasalahan pebelajar dengan penuh empati tanpa menghakimi dan untuk membantu para pebelajar untuk mencapai tujuan pebelajaran bahasa.

c. Guru bahasa berfungsi sebagai seorang motivator; guru bahasa memberi pujian dan dorongan agar para siswa melakukan usahausaha yang positif. Fungsi ini bias dilakukan dengan memberi umpan balik positif terhadap tugastugas yang dikembalikan.

d. Guru bahasa berfungsi sebagai seorang peninjau (observer). Guru menunjukkan kesalahan-kesalahan yang dilakukan oleh para pebelajar dan mengarahkan mereka untuk melakukan tugas-tugasnya dengan benar.

e. Guru bahasa berfungsi sebagai model untuk menghasilkan ungkapanungkapan yang benar dan juga sebagai hakim yang menentukan kapan peran serta pebelajar dilibatkan dalam kegiatan pembelajaran dan menentukan apakah usaha-usaha mereka relevan dan benar.

f. Guru bahasa berfungsi sebagai seorang sumber pengetahuan dan penentu arah pembelajaran. Guru mengambil posisi dominan terhadap para pebelajar dalam memilih bahan-bahan yang akan dipelajari dan juga bagaimana cara menguasai bahan-bahan tersebut.

Peran guru secara otomatis akan menentukan peran para pebelajar bahasa. Ketika seorang guru bahasa sangat dominan, maka para pebelajar bahasa akan kurang dominan dalam interaksi pembelajaran. Beberapa metode telah dikritik karena membuat para pebelajar bahasa menjadi perespons mekanik untuk stimulusstimulus yang disampaikan kepada mereka, yang berakibat pada terjadinya pengulangan-pengulangan. Para pebelajar bahasa akan lebih aktif dalam pembelajaran manakala seorang guru bahasa lebih banyak diam di dalam kelas. Pola hubungan peranan pebelajar bahasa dan guru jumlahnya banyak dan berbeda-beda antarsatu metode dengan metode lainnya.

Beberapa metode menegaskan bahwa guru dan pebelajar bahasa harus berada dalam pola hubungan yang seimbang, sementara beberapa metode yang lain, peran guru bahasa diposisikan lebih tinggi karena dianggap sebagai sumber utama dari berbagai keterampilan dan pengetahuan dalam pembelajaran bahasa. Johnson dan Paulston menjelaskan lima peran pebelajar yang memungkinkan para pebelajar menjadi lebih otonom sebagai berikut.

${ }^{16}$ Richards dan Rodgers, op. cit., h. 28. 


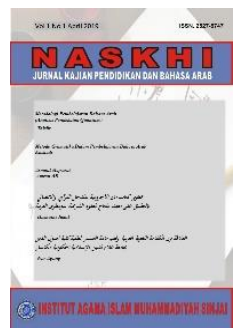

NASKHI

Jurnal Kajian Pendidikan dan Bahasa Arab

Volume 2, No. 1, 2020

ISSN (print) : 2527-5747

ISSN (online) : 2716-3369

Homepage : https://journal.iaimsinjai.ac.id/index.php/naskhi

a. Para pebelajar merencanakan program pebelajaran mereka sendiri dan karena itu pada akhirnya menuntut tanggung jawab atas apa yang mereka lakukan di dalam kelas.

b. Para pebelajar memonitor dan mengevaluasi kemajuan mereka sendiri.

c. Para pebelajar adalah anggota dari suatu kelompok dan mereka belajar dengan saling berinteraksi dengan yang lainnya.

d. Para pebelajar adalah tutor pribadi bagi para pebelajar yang lain.

e. Para pebelajar belajar dari guru, dari siswa yang lain, dan dari sumber belajar yang lainnya ${ }^{17}$.

Komponen terakhir dalam tingkat desain berhubungan dengan peran materi pembelajaran di dalam system pembelajaran. Apa yang ditetapkan berkenaan dengan sasaran akhir, isi (dalam silabus), aktivitas pebelajaran, dan peran pebelajar serta guru akan menentukan fungsi materi pembelajaran. Materi pembelajaran lebih lanjut menjabarkan isi pokok bahasan dalam silabus, dan menentukan atau menggariskan tingkat pemenuhan materi silabus, mengalokasikan waktu, perhatian, dan bagian-bagian detail dari materi dalam silabus atau tugastugas yang diperlukan. Bahan-bahan pembelajaran juga menggambarkan atau menyiratkan sasaran akhir pembelajaran sehari-hari yang secara bersama merealisasikan sasaran dari silabus. Bahan ajar dirancang dengan asumsi bahwa pembelajaran yang dilaksanakan dan dimonitor oleh guru harus memenuhi berbagai tuntutan yang berbeda-beda dari siswa sendiri.

Sebuah rancang-bangun dari suatu sistem instruksional dapat mengimplikasikan seperangkat peranan khusus bagi materi ajar dalam penunjangan silabus dan para pengajar serta para pebelajar. Sebagai misal, peranan materi instruksional atau bahan ajar dalam Metode Komunikatif dapat dijelaskan sebagai berikut:

a. Bahan atau materi ajar akan berpusat pada kemampuan-kemampuan komunikatif mengenai interpretasi, ekspresi, dan negosiasi (penafsiran, pengungkapan, dan perundingan).

b. Bahan atau materi ajar akan berpusat atau berfokus pada pertukaranpertukaran informasi yang mudah dipahami, relevan, dan menarik, bukan melulu pada penyajian bentuk gramatikal.

c. Bahan atau materi ajar akan mencakup berbagai ragam teks dan berbagai jenis media, yang dapat digunakan oleh para pembelajar untuk mengembangkan kompetensi mereka melalui beraneka ragam kegiatan dan tugas.

Peranan bahan ajar atau materi instruksional di dalam suatu system instruksional yang terarah dapat mencakup hal-hal berikut:

a. Bahan/materi ajar akan memungkinkan para pembelajar untuk maju dan berkembang sesuai dengan kecepatan-belajar mereka masing-masing.

b. Bahan atau materi ajar akan memungkinkan adanya gaya belajar yang beraneka ragam.

c. Bahan/materi ajar akan memberikan kesempatan bagi studi dan penggunaan mandiri.

\section{${ }^{17}$ Ibid.}




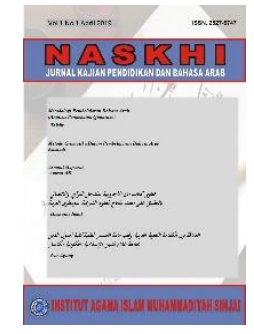

\section{NASKHI}

Jurnal Kajian Pendidikan dan Bahasa Arab

Volume 2, No. 1, 2020

ISSN (print) : 2527-5747

ISSN (online) : 2716-3369

Homepage : https://journal.iaimsinjai.ac.id/index.php/naskhi

d. Bahan atau materi ajar akan memberikan kesempatan bagi siswa untuk mengevaluasi kemajuan mereka dalam pembelajaran. ${ }^{18}$

\section{Teknik (Uslûb Ijrâ'îTechnique)}

Perbedaan antara metode-metode dapat dengan mudah diamati dari tekniktekniknya. Teknik bersifat implemantasional (tercirikan ketika dilakukan). Maksudnya, suatu teknik adalah apa yang benar-benar berlangsung dalam kelas pembelajaran bahasa, atau sebuah strategi khusus yang digunakan untuk mencapai sasaran. Semua aktivitas yang berlangsung di suatu kelas bahasa adalah teknik. Teknik bergantung pada imajinasi guru dan kreativitasnya, serta komposisi kelas. Para guru bahasa bias mengembangkan teknik-tekniknya sendiri sepanjang masih konsisten dengan asumsi-asumsi atau teori-teori dan metode yang menjadi landasan pengembangan teknik-tekniknya. Penggunaan media tape recorder, radio, CD interaktif, multimedia, closed-circuit television, chart tembok, kartu flash, dan sebagainya dalam pengajaran bahasa adalah contoh-contoh teknik.

Satu persoalan dapat diatasi dengan berbagai macam teknik. Kegunaan dan efektivitas berbagai macam teknik dalam pengajaran dan pebelajaran bahasa banyak bergantung pada metode dan pendekatannya. Berikut ini adalah beberapa contoh teknik mengoreksi kesalahan siswa dalam kelas bahasa.

a. Guru tidak memberikan pujian atau kritik sehingga para pebelajar bahasa dapat belajar untuk mengandalkan diri mereka (Metode Guru Diam).

b. Guru sering kali member pujian ketika seorang siswa melakukan suatu hal yang baik dalam pembelajaran (Metode Audiolingual).

c. Ketika seorang siswa membuat ungkapan yang salah, guru hanya mengulangi yang benar (Metode Respons Fisik Total).

d. Guru tidak mempedulikan seorang siswa yang melakukan kesalahan selama kesalahan itu tidak merintangi terjadinya komunikasi (Metode Alamiah).

Teknik tidak terbatas hanya pada penyajian materi bahasa tetapi juga terkait dengan pengulangan materi. Oleh karena itu, posisi suatu teknik adalah pada tahap implementasi dan ia sering disebut prosedur, sedangkan pendekatan dan metode berada pada tingkat desain ${ }^{19}$.

\section{Landasan Teoretis Metode}

Ada kategorisasi tentang metode, di antaranya: metode tradisional (altharîqah al-taqlîdiyyah) seperti metode qawâ'id tarjamah, dan metode modern (al-tharîqah al-al-mu'âshirah), seperti metode respons fisik total dan holistik (whole language). Kategorisasi ini didasarkan pada ada tidaknya teori yang mendasari metode tersebut.

Ada dua kerangka teori yang mendasari sebuah metode sehingga ia disebut modern, yaitu: (1) teori linguistik, dan (2) teori psikologi pembelajaran bahasa. Kedua landasan teori tersebut dijadikan dasar untuk mengembangkan metode pembelajaran bahasa yang kemudian melahirkan berbagai metode baru dengan segala kelebihan dan kekurangannya. Karena setiap metode memiliki kelebihan

\footnotetext{
${ }^{18}$ Richards dan Rodgers, op. cit., h. 30.

${ }^{19}$ Richards dan Rodgers, op. cit., h. 20.
} 


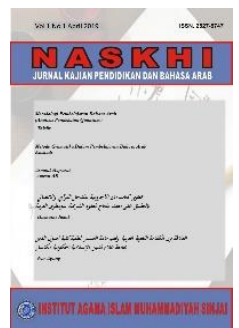

NASKHI

Jurnal Kajian Pendidikan dan Bahasa Arab

Volume 2, No. 1, 2020

ISSN (print) : 2527-5747

ISSN (online) : 2716-3369

Homepage : https://journal.iaimsinjai.ac.id/index.php/naskhi

dan kekurangan, maka tidak ada metode terbaik; yang ada adalah metode yang paling sesuai.

Teori psikologi pembelajaran bahasa menegaskan bahwa orang yang belajar bahasa harus mengalami proses stimulusrespons (al-mutsîr wa alistijâbah). Artinya, belajar bahasa menuntut keaktifan pembelajar dan pebelajar (siswa) atau menuntut stimulus dari guru dan respons dari siswa secara bergantian. Teori pembelajaran ini memanfaatkan bentuk keterampilan dialog (hiwâr) atau Tanya jawab. Jadi, guru-siswa harus terampil bertanya dan menjawab secara spontan. Dalam kaitan ini, apa yang disebut stimulus tidak harus datang dari pihak luar atau dari orang lain, melainkan bisa diciptakan oleh pebelajar sendiri. Contohnya, saat membaca buku, siswa berinteraksi dengan apa yang ia baca.

\section{Aliran Behaviorisme}

Thorndike (salah seorang tokoh behaviorisme) berpendapat bahwa belajar bahasa dilakukan dengan teori trial and error yang bisa dilakukan oleh guru dengan melatihkan pembelajar secara berulang-ulang. Ini menuntut guru untuk pandai merekayasa lingkungan pembelajaran sehingga tercipta komunikasi yang produktif. Atas dasar pandangan ini, muncul metode alsam iyyah al-syafawiyyah (auraloral approach). Metode ini melatihkan kemahiran pendengaran, kemudian melatihkan pengucapan secara baik dan benar. Siswa yang terbiasa menangkap apa yang ia dengar akan lebih mudah menangkap apa yang ia baca. Metode ini menitik-beratkan pada kegiatan reinforcement (al-ta'zîz), yaitu penguatan dengan pengulangan. Media kegiatan reinforcement bisa berupa tadrîbât (latihan), menghafal kosakata dalam kalimat, dialog, dan latihan polapola kalimat yang diharapkan dapat menjadi malakah, yakni keterampilan berbahasa oral (lisan).

\section{Aliran Kognitivisme}

Aliran ini menyatakan bahwa lingkungan bukan penentu hasil pembelajaran. Saat menerima stimulus, pebelajar berhak untuk menentukan pilihan respons yang sesuai dengan tuntutan kebutuhannya. Pengikut aliran ini adalah Noam Chomsky yang berpendapat bahwa setiap orang memiliki kesiapan fitrah (potensi) untuk belajar bahasa termasuk belajar bahasa asing. Artinya: tidak ada justifikasi bahwa seseorang tidak memiliki bakat terhadap bahasa tertentu dan hanya berbakat untuk mempelajari bahasa yang lain. Sekiranya ada justifikasi demikian, tentu itu hanya sebuah bentuk keluhan tanda frustrasi. Sejak lahir, setiap orang telah dibekali Allah Swt. Piranti pemerolehan bahasa atau Language Acquisition Device (LAD). Karena itu, dalam hal berbahasa, ada dua istilah yang perlu dipahami, yaitu (1) ta'allum al-lughah dan (2) iktisâb al-lughah. Yang pertama menunjukkan belajar bahasa berkurikulum, sedangkan yang kedua belajar bahasa dalam lingkungan masyarakat pengguna bahasa yang dipelajarinya.

Teori linguistik atau teori kebahasaan turut mendasari lahirnya metode dan perkembangannya. Teori ini mendasari cara pandang terhadap hakikat bahasa yang melahirkan dua aliran, yaitu: 


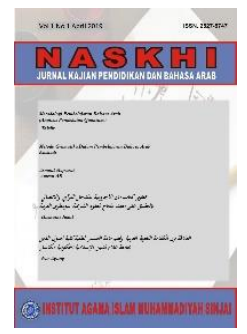

NASKHI

Jurnal Kajian Pendidikan dan Bahasa Arab

Volume 2, No. 1, 2020

ISSN (print) : 2527-5747

ISSN (online) : 2716-3369

Homepage : https://journal.iaimsinjai.ac.id/index.php/naskhi

a. Aliran Struktural yang dipelopori oleh Ferdinand de Saussure. Menurut aliran ini, bahasa adalah:

1) Ujaran (lisan) dan bukan tulisan. Ini artinya, bahwa tagihan belajar bahasa asing adalah kemampuan bercakap.

2) Kemampuan bahasa diperoleh melalui latihan pembiasaan dan pengulangan (al-ta'wîd wa altikrâr). Jadi, bukan mengalihkan dari bahasa pembelajar ke dalam bahasa target (BT) sehingga kesannya seperti menerjemahkan. Pola seperti ini pasti sangat bias bahasa ibu dari pembelajar. Karena itu, tidak mengherankan apabila "aksen dan intonasi" Arab orang Jawa seperti Jawa, dan orang Sunda seperti Sunda. Begitu pula Arab orang Jepang yang berintonasi layaknya bahasa Jepang.

3) Setiap bahasa mempunyai system yang berbeda dari yang lain. Guru bahasa Arab semestinya tahu bahwa struktur bahasa Arab ada yang ismiyyah (diawali dengan kata isim/ benda) dan ada pula yang fi 'liyyah (diawali dengan kata $\left.f i{ }^{\prime} i l / k e r j a\right)$, sedangkan dalam bahasa Indonesia hanya terdapat struktur ismiyyah.

4) Tidak ada bahasa yang bias dinyatakan unggul atas bahasa yang lain, karena semua bahasa hadir sesuai kodratnya masing-masing.

5) Semua bahasa yang hidup mengalami perkembangan, baik kosakata maupun pola dan strukturnya, kecuali bahasa yang tidak hidup atau mati.

Aliran struktural juga memandang bahwa sumber baku bahasa adalah penutur bahasa, sehingga muncul ungkapan "bahasa adalah apa yang diucapkan dan bukan apa yang seharusnya diucapkan." Contohnya, ungkapan "ana muwazhzhaf' bukan "ana muwazhzhif', "hâdza masjid" bukan "hâdza masjad", "ana masrûr(un)" bukan "ana sârr(un)" dan sebagainya.

Menurut aliran struktural, ada beberapa ketentuan dalam proses pembelajaran bahasa, yaitu:

1) Pembiasaan, latihan, dan peniruan harus diintensi $\square$ kan.

2) Kemahiran berbahasa harus dimulai dari mendengar, berbicara, membaca dan menulis. Penyajian bahasa harus mengarah pada penguatan pada empat kemahiran bahasa ini secara lisan dan tulisan.

3) Pendekatan pembelajaran bahasa bisa memanfaatkan analisis kontrastif atau anakon untuk mencari sisi kesamaan antara bahasa pembelajar dengan bahasa target dan mencermati sisi perbedaannya yang dapat digunakan untuk kepentingan frekuensi pelatihan pada sisi mana harus lebih intens.

4) Perlu contoh penuturan yang fasih menyangkut bunyi-bunyi, termasuk yang harus dibaca panjang dan pendek, seperti ucapan "hâdziĥे

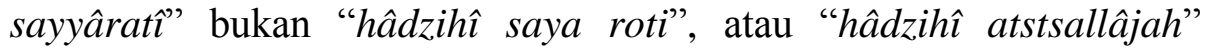
bukan "hâdzihî asalajah". Juga, perlu contoh kefasihan struktur agar tidak terkesan mengarabkan struktur Indonesia atau mengarabkan bahasa daerah. 


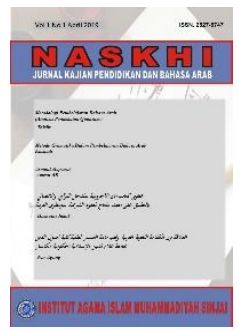

NASKHI

Jurnal Kajian Pendidikan dan Bahasa Arab

Volume 2, No. 1, 2020

ISSN (print) : 2527-5747

ISSN (online) : 2716-3369

Homepage : https://journal.iaimsinjai.ac.id/index.php/naskhi

Selain itu, dua dasar teori linguistic dan teori psikologi pembelajaran bahasa juga melahirkan metode audiolingual.

b. Aliran Generatif Transformasi yang dipelopori oleh Noam Chomsky.

Menurut teori ini, bahasa terdiri dari dua struktur, yaitu struktur dalam (albinyah al- 'amîqah) dan struktur luar (al-binyah al-shathhiyyah). Misalnya, ketika orang mengatakan "al-muwazhzhaf? الموظقف hal itu sama dengan mengatakan "hal anta muwazhzhaf?" Selanjutnya, menurut Chomsky, kemampuan seseorang dalam berbahasa ada dua macam, yaitu kompetensi (al-kafâ'ah) dan performansi (al-adâ'). Ini artinya, kemampuan berbahasa seseorang itu berbeda antara kompetensi dengan performansinya atau tidak berbanding lurus. Kemampuan performansi (aladâ') umumnya lebih rendah daripada kemampuan kompetensinya, baik dalam bahasa lisan maupun dalam bahasa tulisan.

Menurut Chomsky, kemampuan seseorang dalam tata bahasa baru berada pada kompetensi linguistik, belum pada kemahiran berbahasa. Kemampuan seseorang dalam berbahasa juga dapat dibedakan menjadi:

1) kemampuan berbahasa sekadar dapat dipahami (al-lughah almufahhamah)

2) kemampuan berbahasa fasih (allughah al-fashîhah)

3) emapuan berbahasa indah (allughah al-balîghah)

Berdasarkan teori generatif transformasi, pembelajaran bahasa dilakukan dengan mengikuti prinsipprinsip sebagai berikut:

1) Bahwa kemampuan berbahasa merupakan sebuah proses kreatif. Karena itu, pebelajar harus diberi kesempatan yang luas untuk mengkreasi ujaran-ujaran dalam situasi komunikatif, bukan sekadar menirukan dan verbalisme.

2) Pemilihan materi tidak ditekankan pada hasil analisis kontrastif melainkan pada kebutuhan komunikasi.

3) Kaidah nahwu (tata bahasa Arab) hanya diberikan bila diperlukan, dan lebih bersifat implisit bukan eksplisit, untuk mendukung kemahiran berbahasa.

\section{Pengajaran Struktur yang Baik}

Pertu diingat bahwa qawâ 'id (tata bahasa), termasuk struktur atau tarâkîb, bukanlah tujuan pengajaran bahasa, melainkan sarana untuk mencapai tujuan. Karena itu, penting untuk diperhatikan bahwa pengajaran struktur di bawah payung all in one system dilakukan secara implisit saja karena tujuannya adalah untuk mendukung kemahiran berbahasa. Dengan demikian, dalam pengajaran struktur ismiyyah (pola kalimat yang diawali isim), misalnya, perlu diatur permulaannya, batasannya, dan capaiannya, sehingga dapat diketahui kemampuan struktur ismiyyah pola apa saja yang ingin dibelajarkan dan perlu dicapai dalam suatu rangkaian pembelajaran.

Secara teoretis, struktur dapat diajarkan melalui pendekatan deduktif, yaitu mulai dari kaidah baru lalu diikuti dengan contohnya. Contoh-contoh inilah yang nantinya dilatihkan. Karena itu, contoh yang ditampilkan harus merupakan bahasa yang hidup dan komunikatif. Struktur juga dapat diajarkan melalui pendekatan 


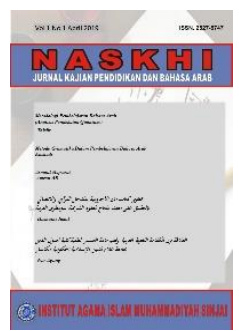

NASKHI

Jurnal Kajian Pendidikan dan Bahasa Arab

Volume 2, No. 1, 2020

ISSN (print) : 2527-5747

ISSN (online) : 2716-3369

Homepage : https://journal.iaimsinjai.ac.id/index.php/naskhi

induktif yang dimulai dengan contoh-contoh, kemudian pebelajar diminta untuk memberi simpulan kaidahnya.

Pembelajaran struktur secara implicit untuk mencapai kemahiran berbahasa dapat menggunakan beberapa media, antara lain:

a. Penggantian tetap, yaitu mengganti satu kata dalam struktur yang sama.

Misalnya:

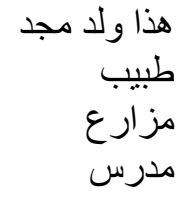

b. Penggantian berpindah, yaitu mengganti satu kata dalam kalimat yang berbedabeda. Misalnya:

$$
\text { ذهب الولا المدرسة }
$$

c. Penggantian ganda, yaitu mengganti dua kata atau lebih dalam sebuah struktur. Misalnya:

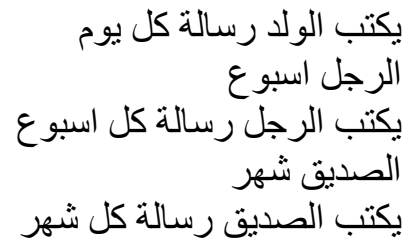

d. Dengan model tahwîl, yaitu mengubah bentuk/pola kalimat. Misalnya, dari ismiyyah menjadi fi 'liyyah atau sebaliknya, dari mubtada' muqaddam menjadi mubtada' mu'akhkhar dan sebagainya. Misalnya:

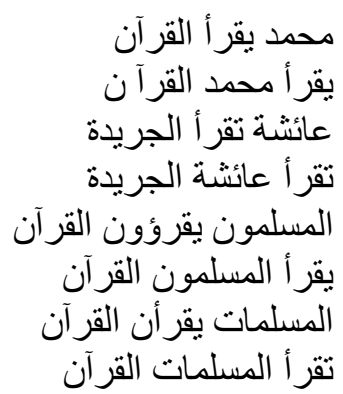

Selanjutnya, pebelajar dilatih dan berlatih sendiri untuk membuat kalimatkalimat seperti contoh di atas, sehingga keterampilan berbahasa terbentuk secara alamiah. Setelah itu, mereka dilatih model perubahan lain sesuai materi atau topic yang dibelajarkan.

\section{Simpulan}

Penyelesaian problem pembelajaran bahasa Arab belum mencapai tingkat keberhasilan yang memadai. Banyak factor yang menyebabkannya, salah satunya adalah persoalan metode pembelajaran yang digunakan. Walaupun demikian, metode hanyalah salah satu dari banyak factor penyebabnya, sementara metode pada saat digunakan terkait dengan faktor-faktor lain, seperti sarana belajar, lingkungan belajar, motivasi belajar, kompetensi guru dan profesionalismenya.

Untuk mengatasi problematika tersebut, hal yang harus dilakukan adalah pembenahan kompetensi dan profesionalisme guru mulai dari jenjang pendidikan 


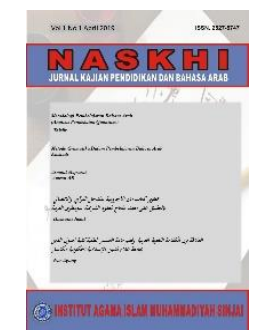

NASKHI

Jurnal Kajian Pendidikan dan Bahasa Arab

Volume 2, No. 1, 2020

ISSN (print) : 2527-5747

ISSN (online) : 2716-3369

Homepage : https://journal.iaimsinjai.ac.id/index.php/naskhi

paling rendah hingga tingkat tinggi. Selain itu, paradigma pembelajaran bahasa Arab harus diubah dari sekadar sebagai alat spiritualisasi menjadi alat saintifikasi, dan perubahan ini harus didukung dengan politik pemerintah baik Indonesia yang mayoritas penduduknya muslim maupun pemerintah negara-negara Arab yang mestinya memiliki semangat kuat untuk mengembangkan masyarakat muslim berbahasa Arab melalui pemberian beasiswa besar-besaran untuk studi lanjut, dan bahkan peluang bekerja di negaranegara Timur Tengah dengan syarat memiliki kompetensi berbahasa Arab yang memadai, baik lisan maupun tulisan.

\section{DAFTAR PUSTAKA}

Abdul Chaer, Psikolinguistik Kajian Teoretik, Jakarta: Rineka Cipta, 2003.

Effendy, Ahmad Fuad, Metodologi Pengajaran Bahasa Arab, Malang: Misykat, 2005.

Fahrurrozi, Aziz dan Erta Mahyudin, Pembelajaran Bahasa Asing, Jakarta: Bania Publishing, 2010.

, Teknik Pembelajaran Kemahiran Bahasa, Jakarta: Bania Publishing, 2011.

Ibrahim, Hamadah, Al-Ittijâhât al-Mu'âshirah fì Tadrîs al-Lughah al-'Arabiyyah wa al-Lughah al-Hayyah al-Ukhrâ li Ghair al-Nâthiqîna bihâ, Kairo: Dar al-Fikr al-Arabi, 1987. al-Ghalayaini, Musthafa, Jâmi“ al-Durûs al'Arabiyyah, Beirut: al-Maktabah al-'Asyriyah, 2003.

al-Khuli, Muhammad 'Ali, Asâlîb Tadrîs al-Lughah al-'Arabiyyah, al-Riyadh: Maktabah al-Farazdaq, 1989.

Mackey, W. F., Language Teaching Analysis, London: Longman, 1965.

Purwo, Bambang Kaswanti, Pragmatik dan Pengajaran Bahasa: Menyibak Kurikulum 1984, Yogyakarta: Kanisius, 1990.

Richards, Jack C. dan Theodore S. Rodgers, Approaches and Methods in Language Teaching, Cambridge: Cambridge University Press, 2001.

Thu'aimah, Rusydî Ahmad, Ta'lîm al-'Arabiyah li Ghair al-Nâthiqîna bihâ, Manâhijuhâ wa asâlîbuhâ, Rabath: Isesco, 1989.

Wright, Tony, Role of Teacher and Learner, Oxford: Oxford University Press, 1987. 